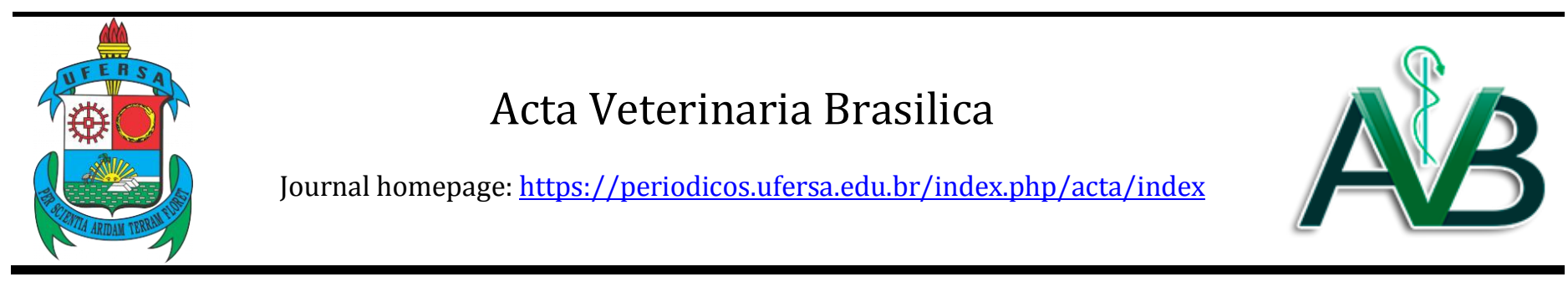

Original Article

\title{
In vitro nematophagous activity of predatory fungi on infective larvae of Strongyloides papillosus
}

\author{
Artur Kanadani Campos ${ }^{1 *}$, Marisa Caixeta Valadãoํㅜ Lorendane Millena de Carvalho ${ }^{1}$, Jackson Victor de Araújo ${ }^{1}$, \\ Marcos Pezzi Guimarães ${ }^{2}$
}

1, Universidade Federal de Viçosa (UFV), Viçosa, Minas Gerais, Brazil

2 Universidade Federal de Minas Gerais (UFMG), Belo Horizonte, Minas Gerais, Brazil

\section{A R T I C L E I N F O}

\begin{tabular}{l}
\hline Article history \\
Received 08 August 2017 \\
Received in revised form 18 September \\
2017 \\
Accepted 27 September 2017 \\
\hline Keywords: \\
Strongyloides papillosus \\
Arthrobotrys \\
Duddingtonia \\
Monacrosporium \\
Nematoctonus \\
Biological Control \\
\hline
\end{tabular}

\author{
A B S T R A C T
}

An in vitro experiment was carried out to assess the effect of fungal isolates of the genus Arthrobotrys, Duddingtonia, Monacrosporium and Nematoctonus on infective Strongyloides papillosus larvae. A suspension of 1,000 infective $S$. papillosus larvae was dripped on to Petri dishes containing fungi grown in agar-water. There was a statistically significant difference $(\mathrm{p}<0.05)$ among all the isolates and the fungus-free control. Comparing the results between isolates, difference was observed in some isolates of the genus Arthrobotrys (CG 719, I40, A1, A2, C1, B1), D. flagrans (CG722), Monacrosporium (CGI, SF53, NF34A) and N. robustus (D1) that showed a better capture and destruction results and consequently a greater decrease in the average of the uncaptured larvae recovered. The results showed that there may be variations in the predatory capacity of different species and among fungal isolates of the same species on Strongyloides papillosus and indicated that nematophagous fungi may be used for the biological control of this helminth.

\section{INTRODUCTION}

Among gastrointestinal parasite of ruminants, Strongyloides papillosus have particular importance in the tropical and subtropical regions of the world. Its life cycle has both parasitic and free-living phases. The parasitic phase consists exclusively of females that produce larvated eggs by parthenogenesis (CHANDRAWATHANI; OMAR; WALLER, 1998; JACOBS et al., 2016; TAYLOR et al., 2016). Infections by this parasite can cause gastrointestinal disturbances (enteritis, diarrhea and loss of appetite), affect body weight and delay growth and sudden death syndrome can occur (MEHLHORN, 2016; PIENNAR et al., 1999; TAIRA et al., 1992).
In Brazil, benzimidazole and macrocyclic lactone anthelmintics are the principal forms of control used against gastrointestinal nematode parasites of ruminants (BOWMAN, 2010; CHARLES; FURLONG, 1996). However, the public health significance of anthelmintic drug residues in products of animal origin, the presence of these drugs in animal feces, their negative influence on biodiversity and agricultural ecosystem sustainability (due to the heavy reliance on systematic and sometimes abusive therapeutic use) and reports of helminth strains tolerant or resistant to different anthelmintic groups have triggered investigation into alternative methods for the sustainable control of gastrointestinal nematodes of ruminants (CAI et al., 2016; GRONVOLD et al., 1996; SUAREZ, 2002). The non-chemotherapeutic approach to the control of nematode gastrointestinal parasites of ruminants using nematophagous fungi as biological

\footnotetext{
*Corresponding author: arturkanadani@gmail.com
} 
control agents showed consistent results (LARSEN, 2000; PAZ-SILVA et al., 2011). Because of differences in the nematophagous capacities of these fungi, studies to distinguish the species and the variations among them are required (ARAÚJO et al., 2004a; CARVALHO; BERNARDO; PAZ-SILVA, 2012).

The purpose of this study was to evaluate the activity of Brazilian isolates of nematophagous fungi of the Arthrobotrys, Duddingtonia, Monacrosporium and Nematoctonus genera against $S$. papillosus larvae in laboratory conditions.

\section{MATERIALS AND METHODS}

Cultures of 17 fungal isolates of the Arthrobotrys, Duddingtonia, Monacrosporium and Nematoctonus genera (Table 1), grown on $1.7 \%$ corn meal agar culture media (CMA, DIFCO ${ }^{\circledR}$ ) in test tubes, were stored at $4^{\circ} \mathrm{C}$ in the dark inside a refrigerator. These nematophagous fungi were isolated from soil samples and ruminant fecal pats from different regions of Brazil.

Table 1 - Species, isolates, origin and trap type of the nematophagous fungi.

\begin{tabular}{|c|c|c|c|}
\hline Species & Isolates & Origin & Trap type \\
\hline Arthrobotrys sp. & E1 & Bovine fecal pat & Adhesive network \\
\hline A. cladodes & CG719† & Bovine decal pat & Adhesive network \\
\hline A. conoides & $\mathrm{I} 40$ & Soil & Adhesive network \\
\hline \multirow{3}{*}{ A. musiformis } & $\mathrm{A} 1 *$ & BovineFecal pat & Adhesive network \\
\hline & $\mathrm{A} 2 *$ & Bovine Fecal pat & Adhesive network \\
\hline & A3* & Bovine Fecal pat & Adhesive network \\
\hline \multirow{2}{*}{ A. oligospora } & C1* & Soil & Adhesive network \\
\hline & $\mathrm{C} 2 *$ & Soil & Adhesive network \\
\hline \multirow{2}{*}{ A. robusta } & $\mathrm{B} 1 *$ & Bovine Fecal pat & Adhesive network \\
\hline & $\mathrm{I} 31^{\ddagger}$ & Soil & Adhesive network \\
\hline \multirow{2}{*}{ Duddingtonia flagrans } & CG722† & Goat fecal pat & Adhesive network \\
\hline & $\mathrm{CG}^{\circ} 68^{\dagger}$ & Goat fecal pat & Adhesive network \\
\hline M. appendiculatum & CGI & Soil & Adhesive network \\
\hline \multirow{2}{*}{ Monacrosporium sinense } & SF53 & Soil & Adhesive network \\
\hline & SF139‡ & Soil & Adhesive network \\
\hline M. thaumasium & NF34A & Soil & Adhesive network \\
\hline Nematoctonus robustus & D1* & Bovine fecal pat & Adhesive knob \\
\hline
\end{tabular}

* Previously isolated by the laboratory staff. +Provided by Genetics and Biotechnology Research unit (Centro Nacional de Pesquisa de Recursos Genéticos e Biotecnologia - CENARGEN), Brasília-DF, Brazi. ‡ Provided by Laboratório de Controle Biológico de FitonematóidesBIONEMA/Universidade Federal de Viçosa, Viçosa-MG, Brazil.

Feces from Saanen goats naturally infected with $S$. papillosus were provided by the clinical pathology laboratory of the Veterinary Department of the Universidade Federal de Viçosa, and were evaluated for fecal egg content. Coprocultures composed of a moistened mixture of $20 \mathrm{~g}$ feces and vermiculite (2:1 ratio) were kept at $26^{\circ} \mathrm{C}$ for 5 days inside an environmental chamber. The infective larvae $\left(\mathrm{L}_{3}\right)$ were recovered from the fecal cultures using Baermann's method and concentrated by gravity inside a glass tube connected to a funnel. To eliminate debris and recover the active and viable $\mathrm{L}_{3}$, the suspension was filtered through Lintguard ${ }^{\circledR}$ paper wipes (Kimberly-Clark, Brazil) according to the methodology described by Barçante et al. (2003). Afterwards, the larvae were washed three times in a $0.05 \%$ chloramphenicol solution (SigmaAldrich, Brazil) and in a $0.05 \%$ streptomycin solution (Sigma-Aldrich, Brazil) by centrifugation at $1,000 \mathrm{rpm}$ for 5 minutes, discarding the supernatant after each centrifugation step. Finally, the larvae were washed twice in distilled water, and their total number was estimated based on the average number in five $20 \mu \mathrm{L}$ aliquots.

The trials for the evaluation of predatory capacity were performed on the surface of $2 \%$ water-agar culture media (2\% WA, Sigma Aldrich, Brazil) contained in $5 \mathrm{~cm}$ diameter Petri dishes.

Mycelial discs of the fungal isolates were transferred from the culture tubes to the center of $9 \mathrm{~cm}$ diameter Petri dishes containing 1.7\% CMA culture media and $0.05 \%$ gentamicin sulfate. These Petri dishes were kept at $25^{\circ} \mathrm{C}$ in the dark inside a BOD (Biochemical Oxygen Demand) incubator. After 7 days, mycelial discs ( $4 \mathrm{~mm}$ in diameter) were removed from the edges of the pure colonies and transferred to $5 \mathrm{~cm}$ diameter Petri dishes containing 2\% WA. The Petri dishes were kept, as described above, until complete grow on surface of the culture media. On the seventh day of incubation, $50 \mu \mathrm{L}$ of a suspension containing approximately $1,000 S$. papillosus $\mathrm{L}_{3}$ were dripped onto the surface of the culture media in each Petri dish. These Petri dishes were 
incubated again for 7 days, as previously described, and evaluated daily for the presence of predatory structures and number of larvae captured. The Petri dishes for the fungus-free control contained $\mathrm{L}_{3}$ without fungi. On the seventh day of incubation, the $2 \%$ WA was removed using a metal spatula, and Baermann's method was used over 6 hours to recover uncaptured larvae into a $5 \mathrm{~mL}$ BD Vacutainer ${ }^{\circledR}$ glass tube (Becton Dickinson, Brazil). The volume in these tubes was equalized to $3 \mathrm{~mL}$, and the number of larvae recovered were counted in five 50 $\mu \mathrm{l}$ aliquots to estimate their total.

The experiment was carried out once in a completely randomized design. For the experimental assay, a total of 17 treatments plus the control group with five replicates each were made. The results were analyzed by analysis of variance. For this, the data were transformed by $\log (\mathrm{x}+1)$, and the average numbers were compared using Tukey's test at a 5\% level of significance. For statistical analysis, the System for Statistical Analyses (SAEG) was used (SAEG, 2007).

The rate of predation was calculated by comparing the mean of larvae recovered from the fungus-free controls and the treatments, using the following formula:

$$
\text { Percent reduction }(\%)=\frac{X c-X t}{X c} .100
$$

In this equation, $\mathrm{Xc}=$ the mean of larvae recovered from the fungus-free control, and $\mathrm{Xt}=$ the average number of larvae recovered from the treatment.

\section{RESULTS AND DISCUSSION}

All fungal isolates tested colonized the $2 \% \mathrm{WA}$, but some isolates showed less growth, taking more time to reach the edges of the Petri dish. Only the fungus $N$. robustus (isolate D1) produced adhesive knob traps spontaneously in the absence of $S$. papillosus $\mathrm{L}_{3}$, whereas the other fungal isolates tested produced adhesive network traps 24 hours after the addition of larvae to the Petri dishes.

Trap formation by nematophagous fungi can occur spontaneously (ARAÚJO et al., 1992; MENDOZA-DEGIVES et al., 1994) or in reason of the presence of nematodes and/or substances released by them as well as under adverse culture conditions resulting from a shortage of water and/or nutrients (BALAN; GERBER, 1972; CAMPOS; ARAÚJO; GUIMARÃES, 2008; HSUEH et al., 2013; JANSSON; NORDBRING-HERTZ, 1980). In the present study, the presence of prey induced the formation of trapping structures in the fungal isolates tested, except in the isolate of $N$. robustus that produced traps spontaneously before addition of the nematode, indicating that these fungi are dependent on the stimuli provided by the nematodes to capture them. MendozaDe-Gives et al. (1994) and Fernández; Saumell (2012) suggested that the ability to form traps spontaneously offers a direct competitive advantage to spontaneous trap-forming predatory fungi over non-spontaneous trap-forming predatory fungi and that the former are more effective at preying on nematodes. Stirling (2014) reported that such ability is associated with a reduction in the saprophytic ability of the fungus and would result in greater predatory efficacy. In fact, this present work, the treatment with the $N$. robustus isolate (D1) in comparison to the some isolates of the genus Arthrobotrys (E1, A3, C2, I31), D. flagrans (CG768) and $M$. sinense (SF139), showed the highest nematicidal activity.

After seven days of interaction between S. papillosus and the fungal isolates, a significant difference $(\mathrm{p}<0.05)$ was found in the average number of larvae recovered per plate of treated groups when compared to fungus-free control. All isolates showed potential use in the reduction of $S$. papillosus larvae. However, some isolates of the genus Arthrobotrys (CG 719, I40, A1, A2, C1, B1), D. flagrans (CG722), Monacrosporium (CGI, SF53, NF34A) and $N$. robustus (D1) showed highest percentages of larval reduction, being considered as potentials candidates for future in vivo studies. The isolates (E1 and C2) of the genus Arthrobotrys had the smallest percentages of reduction, show the lowest nematodecapturing ability when compared to the others, and this may be related to the individual characteristic of the strain, which should be improve elucidated in future studies with these fungus. The average number of larvae recovered per plate and the respective percentages of reduction for each fungal isolate are shown in Table 2.

Previous in vitro investigations showed the predatory activity of some of the fungal isolates tested in the present study on other nematode species. For example, Maciel et al. (2009) evaluated the effect of different conidial concentrations of 12 fungal isolates from the genera Arthrobotrys, Duddingtonia, Nematoctonus and Monacrosporium on Ancylostoma spp. dog infective larvae and they observed that fewer $\mathrm{L}_{3}$ were recovered as fungal inoculum increased in the tested groups. Mota; Bevilaqua; Araújo (2000) reported that A. conoides and $M$. thaumasium isolates caused reductions of $67.9 \%$ and $91.9 \%$, respectively, in the number of $H$. contortus infective larvae recovered from WA contained in Petri dishes after 20 days of interaction.

There is little information with regard to the activity of nematophagous fungi on $S$. papillosus larvae. Roubaud; Deschiens (1941) observed a less number of $S$. papillosus larvae in pastures grazed by sheep that were treated with the fungi $A$. oligospora, Dactylella bembicoides and Dactylaria ellipsospora. Gonzalez-Cruz; Mendoza-deGives; Quiroz-Romero (1998) compared the predatory activity of the fungi $A$. robusta and M. gehyropagum on $S$. papillosus and observed $32.3 \%$ and $93.1 \%$ reductions in the total of larvae recovered, respectively. Chandrawathani et al. (1998) studied the effect of $A$. 
oligospora on $S$. papillosus larvae in coprocultures and observed a $99 \%$ reduction in the total of larvae recovered when $A$. oligospora was used at a concentration of 2,000 conidia per gram of feces. Campos et al. (2009) evaluated the effect of fungal structures on the number of gastrointestinal larvae of Haemonchus contortus and S. papillosus harvested from fecal goat cultures and noted that $D$. flagrans survived the passage through the gastrointestinal tract of goats and maintained its predatory activity.

Table 2 - The average number of Strongyloides papillosus larvae recovered per plate (ANLRP*) ( $\mathrm{n}=5$ ) and the percent reduction after seven days interaction with different isolates of nematophagous fungi.

\begin{tabular}{ccc}
\hline Isolates & ANLRP* & Percent reduction (\%) \\
\hline Arthrobotrys sp.(E1) & $217.2^{\mathrm{bc}}$ & 77.3 \\
A. cladodes (CG719) & $4.8^{\mathrm{g}}$ & 99.5 \\
A. conoides (I40) & $0 \mathrm{~g}$ & 100 \\
A. musiformis (A1) & $9.6^{\mathrm{fg}}$ & 99.0 \\
A. musiformis (A2) & $0 \mathrm{~g}$ & 100 \\
A. musiformis (A3) & $132.0^{\mathrm{cd}}$ & 86.2 \\
A. oligospora (C1) & $12.0^{\mathrm{fg}}$ & 98.7 \\
A. oligospora (C2) & $331.2^{\mathrm{b}}$ & 65.4 \\
A. robusta (B1) & $0 . \mathrm{g}$ & 100 \\
A. robusta (I31) & $112.8^{\mathrm{de}}$ & 88.2 \\
Duddingtonia flagrans (CG722) & $12.0^{\mathrm{fg}}$ & 98.7 \\
Dlagrans (CG768) & $43.2^{\mathrm{ef}}$ & 95.5 \\
M. sinense (SF53) & $7.2^{\mathrm{fg}}$ & 99.2 \\
M. sinense (SF139) & $9.6^{\mathrm{fg}}$ & 99.0 \\
M. thaumasium (NF34A) & $198.0^{\mathrm{cd}}$ & 79.3 \\
\hline Futoctonus robustus (D1) & $0^{\mathrm{g}}$ & 100 \\
\hline
\end{tabular}

Means followed by the same superscripts do not differ by a Tukey's test $(\mathrm{p}<0.05)$. The original values are expressed in arithmetic media, but the statistical analysis was performed with the $\ddot{O}(\mathrm{x}+1)$ transformation. *Average number of $S$. papillosus larvae recovered per plate $(\mathrm{n}=5)$.

Field investigations have proven the effectiveness of nematophagous fungi on nematodes of grazing animals. Alves et al. (2003) and Araújo et al. (2004b) observed the efficacy of a fungal isolate of $M$. thaumasium, with a reduction in the number of eggs per gram of feces (EPG) in treated animals ranging from $88 \%$ to $100 \%$. Graminha et al. (2005) evaluated the oral administration of the fungus Arthrobotrys musiformis (conidia microencapsulated in alginate or in natural liquid medium) for sheep. The results demonstrated that the fungus was effective even after passage through the gastrointestinal tract of sheep, and showed no change in its predatory capacity for larvae of nematode parasites. Vilela et al. (2016) used coadministration of the fungi $D$. flagrans and $M$. thaumasium against gastrointestinal helminths in young and adult sheep in northeastern Brazil. Reductions in EPG of $76 \%$ in adult and $83 \%$ in young sheep were observed. Assis et al. (2012) also used an isolate of $D$. flagrans to reduce reinfection by Trichostrongylus in beef cattle and observed a significant reduction in EPG (56.7\%) and $\mathrm{L}_{3}$ larvae (60.5\%) recovery from coprocultures. Assis; Araújo (2003) observed a $68.2 \%$ reduction in coprocultures of equine feces after administering $100 \mathrm{~g}$ of a pellet formulation containing sodium alginate and the Monacrosporium isolate fungus to the animals.
In this study, statistically significant differences in predatory capacity were observed between isolates of the same species. Isolates I31 and B1 of $A$. robusta, SF53 and SF139 of $M$. sinense, A1 and A3 of A. musiformis and $\mathrm{C} 1$ and $\mathrm{C} 2$ of $A$. oligospora showed different predatory capacity. Intraspecific and interspecific variations in the activity of nematophagous fungi on nematodes have already been observed. In vitro tests performed by Araújo et al. (1993; 1994) demonstrated that isolates of $A$. robusta and $A$. musiformis showed different levels of virulence on H. placei. Naves; Campos (1991) reported variations in the predatory capacity of isolates of $A$. conoides and A. musiformis on Panagrellus redivivus. According to Stirling (2014), variations in virulence among isolates may be a reflection of genetic differences.

In vitro studies may overestimate the activity of nematophagous fungi because in these conditions, they are not exposed to parasitism and predation by the diverse micro and mesofauna present in the natural environment. Moreover, the nematodes have little chance of escaping the attack (ARAÚJO et al., 1993). On the other hand, in vitro tests are important for the selection of promising isolates of nematophagous fungi that have potential for use as biocontrol agents against parasitic nematodes. These studies generally require minimal space, are rapid, simple and inexpensive to 
perform, provide important information and can be conducted under controlled conditions allowing a higher level of control of the fungus-nematode interactions (FERRAZ; SANTOS, 1995).

Maintenance of fungal isolates in culture over prolonged periods under laboratory conditions by regular subculturing can result in the occurrence of mutations or genetic variability that may be reflected by a loss of viability due to alterations in pathogenicity, virulence or basic features (GERHARDT, 1981). These alterations can occur rapidly, and in a few generations, the isolate can show little resemblance to the original strain (FAEDO; LARSEN; WALLER, 1997; VAN OORSCHOT, 1985). Several isolates that were evaluated in the present study were preserved in a laboratory for several years, and this may have led to harmful alterations that would have resulted in a decrease in predatory efficacy. Data from our in vitro tests cannot be extrapolated to predict responses in the field. Therefore, additional studies to assess the effect of nematophagous fungi on parasitic nematodes of ruminants in fecal cultures as well as fungal viability testing after passage through the gastrointestinal tract of different species of ruminants are required. Another alternative would be the spraying of conidia and chlamydospores of fungi in the environment.

The results of new studies will provide important information for implementing biological control programs.

\section{CONCLUSION}

Nematophagous fungi could provide benefits to intensive animal husbandry by controlling nematode parasites of ruminants, such as $S$. papillosus. We must consider that is an innovative and promising alternative to helminths control.

\section{ACKNOWLEDGMENTS}

The authors are grateful to the Conselho Nacional de Desenvolvimento Científico e Tecnológico (CNPq) and Fundação de Amparo à Pesquisa do Estado de Minas Gerais (FAPEMIG) for their financial support of this study.

\section{REFERENCES}

ALVES, P.H et al. Aplicação de formulação do fungo predador de nematóides Monacrosporium thaumasium (Drechsler 1937) no controle de nematóides de bovinos. Arquivo Brasileiro de Medicina Veterinária e Zootecnia, v.55, n.5, p.568-573, 2003.

ARAÚJO, J.V. et al. Antagonistic effect of predacious Arthrobotrys fungi on infective Haemonchus placei larvae. Journal of Helminthology, v.67, p.136-138, 1993.

ARAÚJO, J.V. et al. Atividade in vitro dos fungos nematófagos dos gêneros Arthrobotrys, Duddingtonia e Monacrosporium sobre nematóides trichostrongilídeos (Nematoda: Trichostrongyloidea) parasitos gastrintestinais de bovinos. Revista Brasileira de Parasitologia Veterinária, v.13, n.2, p.65-71, 2004a.

ARAÚJO, J.V. et al. Control of bovine gastrointestinal nematode parasites using pellets of the nematode-trapping fungus Monacrosporium thaumasium. Ciência Rural, v.34, n.2, p.457-463, 2004 b.

ARAÚJO, J.V. et al. Biological control "in vitro" of infective Haemonchus placei larvae by predacious fungi Arthrobotrys musiformis. Arquivo Brasileiro de Medicina Veterinária e Zootecnia, v.46, n.3, p.197-204, 1994.

ARAÚJO, J.V. et al. Controle de larvas infectantes de Haemonchus placei por fungos predadores da espécie Monacrosporium ellypsosporum em condições de laboratório. Arquivo Brasileiro de Medicina Veterinária e Zootecnia, Belo Horizonte, v.44, p.521-526, 1992.

ASSIS, R.C.L. et al. Biological control of trichostrongyles in beef cattle by the nematophagous fungus Duddingtonia flagrans in tropical southeastern Brazil. Experimental Parasitology, v.132, p.373-377, 2012.

ASSIS, R. C. L.; ARAÚJO, J.V. Avaliação da viabilidade de duas espécies de fungos predadores do gênero Monacrosporium sobre ciatostomíneos após a passagem pelo trato gastrintestinal de eqüinos em formulação de alginato de sódio. Revista Brasileira de Parasitologia Veterinária, v.12, n.3, p.109-113, 2003.

BALAN, J.; GERBER, N. Attraction and killing of the nematode Panagrellus redivivus by the predacious fungus Arthrobotrys dactyloides. Nematologica, v.18, n.2, p.163-173, 1972.

BARÇANTE, J.M.P. et al. A method to obtain axenic Angiostrongylus vasuorum first-stage larvae from dog feces. Parasitology Research, v.89, n.2, p.89-93, 2003.

BOWMAN, D.D. Parasitologia Veterinária de Georgis, 9.ed, Elsevier, 2010. 432p.

CAI, K.Z. et al. Screening of different sample types associated with sheep and cattle for the presence of nematophagous fungi in China. Journal of Basic Microbiology, v.56, n.3, p.214-228, 2016.

CAMPOS, A.K. et al. Resistance of different fungal structures of Duddingtonia flagrans to the digestive process and predatory ability on larvae of Haemonchus contortus and Strongyloides papillosus in goat feces. Parasitology Research, v.105, p.913-919, 2009.

CAMPOS, A.K.; ARAÚJO, J.V.; GUIMARÃES, M.P. Interaction between the nematophagous fungus Duddingtonia flagrans and infective larvae of Haemonchus contortus (Nematoda: Trichostrongyloidea). Journal of Helminthology, v.82, p.337-341, 2008.

CARVALHO, L.M.M.; BERNARDO, F.A.; PAZ-SILVA, A. The role of fungi in the control of animal parasites - classification, mode of action and practical applications. In: PAZ-SILVA, A.; SOL, M. (Ed). Fungi: Types, Environmental Impact and Role in Disease. New York: Nova Science Publishers, 2012, Chapter XIV, p.271-308.

CHANDRAWATHANI, P.; OMAR, J.; WALLER, P. The control of the freeliving stages of Strongyloides papillosus by the nematophagous fungus Arthrobotrys oligospora. Veterinary Parasitology, v.76, p.321-325, 1998.

CHARLES, T.P.; FURLONG, J. A survey of dairy cattle worm control practices in Southeast Brazil. Veterinary Parasitology, v.65, p. 65-73, 1996.

FAEDO, M.; LARSEN, M.; WALLER, P.J. The potential of nematophagous fungi to control the free-living stages of nematodes parasites of sheep: Comparison between Australian isolates of Arthobotrys spp. and Duddingtonia flagrans. Veterinary Parasitology, v.72, p.149-155, 1997. 
FERNÁNDEZ, S.; SAUMELL, C. Biological control of parasites in Veterinary Medicine. In: PAZ-SILVA, A.; SOL, M. (Ed). Fungi: Types, Environmental Impact and Role in Disease. New York: Nova Science Publishers, 2012. Chapter XV, p.309-340.

FERRAZ, S.; SANTOS, M.A. Controle biológico de fitonematóides pelo uso de fungos. Revisão Anual de Fitopatolologia, v.3, p.283-314, 1995.

GERHARDT, P. Manual of Methods for General Microbiology. American Society for Microbiology, Washington, 1981.

GONZALEZ-CRUZ, M.E.; MENDOZA-DE-GIVES, P.; QUIROZ-ROMERO, H. Comparison of the ability of Arthrobotrys robusta and Monacrosporium gehyropagum on infective larvae of Strongyloides papillosus. Journal of Helminthology, v.72, p. 209-213, 1998.

GRAMINHA, E.B.N. et al. Controle de nematoides parasitos gastrintestinais por Arthrobotrys musiformis em ovinos naturalmente infestados mantidos em pastagens. Pesquisa Agropecuária Brasileira, v.40, n.9, p.927-933, 2005.

GRONVOLD, J.et al. Aspects of biological control - with special reference to arthropods protozoans and helminths of domesticated animals. Veterinary Parasitology, v.64, p.47-64, 1996.

HSUEH, Y.P. et al. Nematode-trapping fungi eavesdrop on nematode pheromones. Current Biology, v.23, p.83-86, 2013.

JACOBS, D. et al. Principles of Veterinary Parasitology. Wiley Blackwell, 2016. 736p.

JANSSON, H.B.; NORDBRING-HERTZ, B. Interactions between nematophagous fungi and plant parasitic nematodes: attraction induction of trap formation and capture. Nematologica, v 26, n.4, p.383-389, 1980

LARSEN, M. Biological control of helminths. Internal Journal for Parasitology, v.29, p.139-146, 2000.

MACIEL, A.S. et al. Predation of Ancylostoma spp. dog infective larvae by nematophagous fungi in different conidial concentrations. Veterinary Parasitology, v.161, p.239-247, 2009.

MEHLHORN, H. Encyclopedia of Parasitology. Springer, 4.ed., p.79, 2016.

MENDOZA-DE-GIVES, P. et al. In vitro trapping capability of Arthrobotrys spp on infective larvae of Haemonchus contortus and Nacobus aberrans. Journal of Helminthology, v. 68, p.223-229, 1994.

MOTA, M.A.; BEVILAQUA, C.M.L.; ARAÚJO, J.V. Atividade predatória de fungos Arthrobotrys conoides e Monacrosporium thaumasium sobre larvas infectantes de Haemonchus contortus de caprinos. Ciência Animal, v.10, p.37-41, 2000

NAVES, R.L.; CAMPOS, V.P. Ocorrência de fungos predadores de nematoides no Sul de Minas Gerais e estudos da capacidade predatória e crescimento in vitro de alguns de seus isolados. Nematologia Brasileira, v.15, p.152-162, 1991.

PAZ-SILVA, A. et al. Ability of the fungus Duddingtonia flagrans to adapt to the cyathostomin egg-output by spreading chlamydospores. Veterinary Parasitology, v.179, n.1-3, p.277-282, 2011.

PIENNAR, J.G. et al. Experimental studies with Strongyloides papillosus in goats. Onderstepoort. Journal of Veterinary Research, v. 66, p.191$235,1999$.

ROUBAUD, E.; DESCHIENS, R. Essais relatifs a la prophilaxie de l'anguillulose du mouton par lúsage dês Hiphomycetes predateurs du sol. Comptes Rendus des séance de la Société de Biologie, v.135, p.687-690, 1941.
SAEG. SAEG: sistema para análises estatísticas, versão 9.1. Viçosa: UFV, 2007.

STIRLING, G.R. Biological control of plant-parasitic nematodes: soil ecosystem management in sustainable agriculture. CAB International, Australia. 2014

SUAREZ, V.H. Helminthic control on grazing ruminants and environmental risks in South America. Veterinary Research, v.33, p.563-573, 2002.

TAIRA, N. et al. Sudden death of calves by experimental infection with Strongyloides papillosus. I. Parasitological observations. Veterinary Parasitology, v.42, n.3-4, p.247-256. 1992.

TAYLOR, M.A.; COOP, R.L.; WALL, R.L. Veterinary Parasitology, 4.ed., Wiley Blackwell, 2016. 1006p.

VAN OORSCHOT, C.A.N. Taxonomy of the Dactylaria complex. A review of Arthrobotrys and allied genera. Studies in Mycology, [S.l.], v.26, p.61-95, 1985

VILELA, V.L.R. et al. Coadministration of nematophagous fungi for biological control over gastrointestinal helminthes in sheep in the semiarid region of northeastern Brazil. Veterinary Parasitology, v.221, p.139-143, 2016 